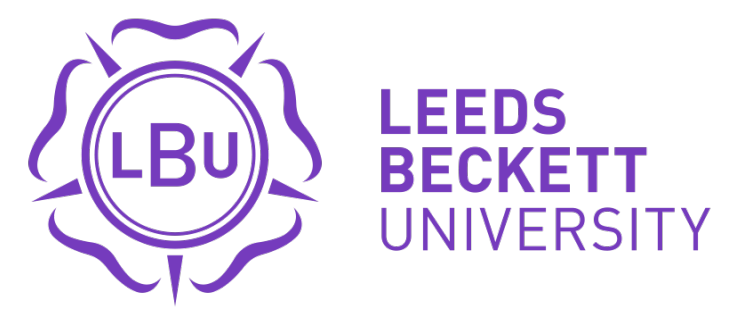

Citation:

Purcell, TF and Martinez, E and Fernandez, N (2018) The Value of Rents: Global Commodity Chains and Small Cocoa Producers in Ecuador. Antipode, 50 (3). pp. 641-661. ISSN 1467-8330 DOI: https://doi.org/10.1111/anti.12380

Link to Leeds Beckett Repository record:

https://eprints.leedsbeckett.ac.uk/id/eprint/4114/

Document Version:

Article (Accepted Version)

This is the peer reviewed version of the following article: Purcell, T. , MartinezEsguerra, E. and Fernandez, N. (2018), The Value of Rents: Global Commodity Chains and Small Cocoa Producers in Ecuador. Antipode, 50: 641-661, which has been published in final form at https://doi.org/10.1111/anti.12380. This article may be used for non-commercial purposes in accordance with Wiley Terms and Conditions for Use of Self-Archived Versions.

The aim of the Leeds Beckett Repository is to provide open access to our research, as required by funder policies and permitted by publishers and copyright law.

The Leeds Beckett repository holds a wide range of publications, each of which has been checked for copyright and the relevant embargo period has been applied by the Research Services team.

We operate on a standard take-down policy. If you are the author or publisher of an output and you would like it removed from the repository, please contact us and we will investigate on a case-by-case basis.

Each thesis in the repository has been cleared where necessary by the author for third party copyright. If you would like a thesis to be removed from the repository or believe there is an issue with copyright, please contact us on openaccess@leedsbeckett.ac.uk and we will investigate on a case-by-case basis. 
Pre-publication final edit for Antipode.

Article accepted 8/09/2017

\title{
The Value of Rents: Global Commodity Chains and Small Cocoa Producers in Ecuador
}

\author{
Thomas F. Purcell
}

School of Social, Psychological \& Communication Sciences, Leeds Beckett University

t.f.purcell@leedsbeckett.ac.uk

\author{
Estefania Martinez E. \\ CENEDET; \\ tefinez@gmail.com
}

Nora E. Fernandez

CENEDET;

norafernandezm@gmail.com

\begin{abstract}
:
Drawing on the Marxian theory of ground rent this paper develops an analysis of "global commodity chains" (GCC) with agrarian roots. There is an acknowledgement that the concentrated downstream governance of primary commodity based GCC has created a set of 'asymmetrical' power relations which blocks the transmission of value upstream towards small producers. This paper argues that this research under-specifies what is meant by value and rent and in doing so marginalises the analysis of value production before its journey through interfirm relations. We demonstrate the importance of theorising the value constitution of commodities produced on the land and the forces that contest the payment of ground rent and thereby shape the geography of GCC. Based on empirical research conducted around Ecuador's 'post-neoliberal' cocoa re-activation plan, we identify the class politics and production mechanisms through which value and rent escapes the hands of a stratified network of small owner producers.
\end{abstract}

Keywords: ground rent, global commodity chains, cocoa, Ecuador, Marx

\section{Acknowledgements:}

We would like to thank Japhy Wilson, the CENEDET team, Greig Charnock, Elisa Greco and three anonymous referees for helpful comments on earlier drafts of this paper. The usual caveats apply. 


\section{The Value of Rents: Global Commodity Chains and Small Cocoa Producers in Ecuador}

\section{Introduction}

In 2008, when visiting a cocoa-producing province in Ecuador's Amazonian region, President Rafael Correa championed the cultivation of 'fine aroma cocoa' as the community's way out of poverty and underdevelopment. Such declarations were in keeping with the mantra of the so-called 'Citizen's Revolution' which brought a left-wing government to power after over two decades of neoliberal reforms. A year later, as part of the government's 'post-neoliberal' development agenda, the cocoa sector was included in a plan inspired by the neostructuralist policies of the Economic Commission for Latin America and the Caribbean (ECLAC) to 'Transform the Productive Matrix' and combat an enduring dependence on the export low value-added primary commodities (ECLAC, 2012:33). This was in keeping with ECLAC's riposte to the structuralist view of southern countries being locked in to 'commodity chains' that reproduce unequal exchange between the 'core' and 'periphery' (Hopkins and Wallerstein 1977). To date the cocoa project has centred on tackling the low productivity of small producers cultivating fine aroma cocoa - a bean with special flavour qualities prized by high cocoa content chocolate manufacturers - in order to reposition and consolidate 'the good name of Ecuador as a producer of the best cocoa in the world' and improve the 'institutional quality of the of the value chain' (MAGAP 2013:2).

The language of value chains and targeted development endorsed by ECLAC comes from the influential and now well established global commodity chain (GCC), and most prominently its later incarnation global value chain (GVC), frameworks (Gereffi and Korzeniewicz 1994; Gereffi 2001). Although chains dependent on the labour intensive cultivation of primary commodities have their own specificities - supply is fixed in place and cannot easily be relocated according to relative costs - scholars have alighted on the analytical ideal types producer driven (PDCC) and buyer-driven (BDCC) to interrogate forms of control over global production chains (Raikes et al. 2000). Given the levels of concentration and centralisation, vertical integration and economies of scale, and the standardised logistical and transportation networks that characterise primary commodity processing and trading, there is consensus that these chains are largely buyer-driven (BDCC) (Gibbon and Ponte 2005; Fold and Pritchard 
Pre-publication final edit for Antipode.

Article accepted 8/09/2017

2005). This can be seen in the widely shared acknowledgement that small farmers are being marginalised by the dynamics of commodity based GVC; that 'added-value' opportunities are being eliminated at the farm gate; and that few upgrading possibilities exist for small farmers (Daviron and Ponte 2005; Humphrey 2006). Whilst this may well be true, there is little direct investigation into producer conditions, forms of ( self)-exploitation, class relations, and patterns of capital accumulation at the root of the chain. The upshot of this has been the marginalisation of research into the production and transfer of value by primary commodity producers. Developing a Marxist approach to ground rent and drawing on a detailed empirical investigation of small cocoa producers in Ecuador, this paper seeks to address this oversight.

The paper builds on the so-called second generation critical theorists, extending to Global Value Chains (GVC) and Global Production Networks (GPN) (cf Bair 2005; Bridge 2008). However, it does so in the vein of recent value-theoretic Marxist contributions which have brought into focus the undertheorisation of production (Taylor 2008); class struggle within chain relations (Selwyn 2012); and the operation of the law of value as the indirect organising principle of inter-firm relations (Starosta 2010a). This research has done much to enhance the critical toolkit of GCC, however, a notable absence has been the mobilisation of the Marxist concept of ground rent in the analysis of commodity chains that extend beyond strictly industrial sectors. Whilst Starosta (2010b) has undertaken a similar task in the context of the electronics industry, here we extend this value-theoretic approach to unpack the historical development of the cocoa commodity chain in Ecuador. This approach recalls Kautsky's (1988) analysis of the way in which agroindustrial capital has the capacity to subsume hybrid forms of petty commodity production in order to extract surplus labour from the direct producers. By locating these specific 'chain' processes within their general relation as expressions of changes in global capitalism, we believe the paper is well placed to take seriously the local and global systemic factors which confront small producers within Ecuador's cocoa project and, in doing so, provide a novel contribution to the GCC/GVC literature (Bair 2005:154).

The paper is organised as follows. Section one outlines our approach to the Marxian concept of ground rent and demonstrates the importance of theorising the value constitution of commodities produced on the land rather than restricting analyses to the payment for use of the land. Section two engages with GCC/GVC research that takes into account the peculiarity of primary commodity exports characterised by a 'catholic' approach to the category of 
Pre-publication final edit for Antipode.

Article accepted 8/09/2017

'economic rent' (Bridge 2008). We argue that this broad epistemological tapestry underspecifies what is meant by value and rent and in doing so marginalises the analysis of value production before its journey through inter-firm relations. Section three takes up this theoretical approach to explain how historical changes in the organisation of the Ecuadorean cocoa GCC were tied to geographical struggles over, and the changing form of, rents. This is dealt with in three phases: the emergence and decline of a national cocoa oligarchy; the limits of state-led development; and the territorial effects of neoliberal deregulation. Section four draws upon our primary research to critically explore the government's new cocoa development plan. ${ }^{1}$ Here we examine the current social and geographical roots of the cocoa commodity chain and identify the mechanisms through which value and rent escapes the hands of a stratified network of small owner producers. The conclusion draws our finding together to highlight the development politics which attach themselves to the cocoa GCC in Ecuador.

\section{Ground Rent and Value}

The cogency of Marx's theory of rent and its applicability to different spheres of capitalist production and distribution has been the subject of intense, but interspersed, periods of academic debate. Within critical geography's spatial turn and across the social sciences more generally, two positions can be discerned: those interested in applying rent to concrete urban or rural contexts (Ball 1985; Haila 1990); and those seeking to locate rent within the general laws of capital accumulation (Harvey 1982; Fine 1979). The former has tended to look outside value theory for its methodological frame, whereas the latter argues that rent theory is internal to the framework of value theory itself, which taken together, provides the link to interrogate the valorisation of capital in different historical geographical circumstances (Harvey, 1982: $332){ }^{2}$ Here we follow the latter approach by differentiating two levels of abstraction: first, a stylised overview of Marx's categories of ground rent; and second, a consideration of concrete circumstances which mediate the flow of ground rent and value between landlords, capital, the state, and small agrarian owner producers. ${ }^{3}$

In Capital Volume III Marx (1991: 799) outlines how, in the primary sector, rents are extraordinary surplus profits based on the landowners' monopoly over non-reproducible natural conditions that increase labour productivity. Unlike industrial products -where 'prices of production' are determined by the average conditions prevailing in the sector - prices of primary commodities are regulated by the marginal (least productive) lands which have to be 
Pre-publication final edit for Antipode.

Article accepted 8/09/2017

brought under production to satisfy solvent demand (Marx 1991: 810; Iñigo Carrera 2007:1113). ${ }^{4}$ Thus surplus profits are available to capital benefitting from lower production costs on more productive lands. However, competition to access better lands allows landowners to increase the rental price and appropriate the surplus in the form of differential rent, thereby equalising profits rates among agricultural capitals (Harvey 1982:361). ${ }^{5}$ Marx also demonstrated - pace Ricardo's claim that all rent must be differential rent - the further existence of absolute and monopoly forms of rent. ${ }^{6}$ The basis of absolute rent is surplus value produced in the primary sector due to lower organic composition of capital (i.e. a greater preponderance of living labour because technological development is lower than the social average) (Harvey 1982:351-3). Landowners are able to retain this surplus value in the form of absolute rent by blocking its outflow and equalisation between sectors. In contrast, monopoly rent arises when the owner can charge a monopoly price. To explain the formation of monopoly rents, Marx famously used the example of a small but high quality vineyard. The owner of a special and limited resource can charge a monopoly price, by which 'we mean any price determined simply by the desire and ability of the buyer to pay, independently of the price of the product as determined by prices of production and value' (Marx, 1981:910). Therefore, a monopoly price creates the rent which is 'levied on consumption' (Harvey 1982:353).

The intention of this brief overview is to illustrate that the social origin of the value appropriated as ground rent differs between its differential, absolute and monopoly phenomenal forms. Yet, because these categories are developed at a higher level of abstraction than the contingencies of the market (Kerr 1996:61), the question of who appropriates the rent, and from whom, can only be answered at the level of empirical investigation (Harvey 1982:365). This approach illustrates how Marx's categories are not restricted to the analysis of ground rent for land owners, but include the extent to which other social subjects can also appropriate ground rent (Iñigo Carrera 2007). For example, in the case of agriculture, land functions as a means of production and the use values produced become ground rent bearing commodities. ${ }^{7}$ Strictly speaking all rent increases the commercial price of commodities and as such are inseparable, but it is only differential and monopoly rents - extra surplus value not retained by the landowner in the form of absolute rent - which enter into the price of the commodity. ${ }^{8}$ Iñigo Carrera (2007:11-13) has shown how the export of ground rent bearing commodities from Latin America constituted an important stream of revenue for the state through specific public policies, such as export taxes and prices controls, which intervene into the rotation cycle of primary commodities to the world market and capture differential and monopoly rent. ${ }^{9}$ 
Pre-publication final edit for Antipode.

Article accepted 8/09/2017

However, policies like export taxes and prices controls are limited with respect to the forces that contest the payment of ground rent and thereby shape the geography of capitalism (Iñigo Carrera, 2007:88-90).

For example, in the case of agroindustrial capital there are three intertwined mechanisms which potentially reduce the payment of ground rent: the extension, where possible, of the agrarian frontier to new lands thus undoing part of the monopoly of lands in production reducing market prices and differential rent; market liberalisation and the dismantling of the state's capacity to create monopoly rent through regulated prices; and striking up indirect supply relations with small owner producers for whom ground rent and even normal profit does not enter into their costs of production (Marx 1981:941-3). The latter case is explained by what Marx (1981:941942) called 'small agrarian capitals' whose 'exploitation is not limited by the average profit on capital' because as a small capital he does not participate in the formation of the average price of production, nor is he limited 'by the need for a rent, in as much as he is a landowner.' The upshot is that small producers provide 'agricultural products at their 'cost price' (which includes the strictly necessary remuneration of labour), as well as putting the totality of his own surplus labour, which would normally correspond to profit and ground rent, at the disposal of the urban economy' (Vergopoulos 1978:447). Although Marx's category of 'small agrarian capital' pertained to the genesis of capitalist ground rent and transitional forms of peasant ownership, historical materialist agrarian scholarship has shown how 'hybrid forms' of primary production, in which peasants depress their real income, could be sustained from the end of the $19^{\text {th }}$ century until the the era of globalisation (Kautsky 1988; Bernstein 2002:418). Thus small scale peasant producers are not a relic of a bygone era, but are constituents of, and constituted by, the reorganisation of production by capital (Barta 2006). This analysis can now be used to problematize the categories of 'added value' and 'economic rents' in the GCC/GVC literature in general and in doing so highlight how this tends to ignore the value relations of primary commodity production that lie below inter-firm chains.

\section{Locating Rents in Primary Commodity Chains}

The application of the GCC and GVC frameworks to primary commodities has shed valuable light on how changes in chain governance structures, technological, processing and shipping capacities have impacted the strategic choices of producer countries and, significantly, those small farmers that sit at the bottom of primary commodity chains (Gibbon and Ponte 2005; 
Pre-publication final edit for Antipode.

Article accepted 8/09/2017

Humphrey 2006). In the case of tropical commodities like coffee, cane sugar, rubber and cocoa chain coordination is characterised by a loose, indirect and competitive form of governance seeking volume, price and reliability from large international traders (Talbot 2002). This organisation of primary exports has been a noted development since the 1980s, following the dismantling of import substitution strategies (ISI) and state marketing boards in exporting countries. This saw financial, purchasing and processing power accumulated in the hands of a few international firms that manage sophisticated containerized logistical networks, control huge processing capacity and work according to Just-in-Time (JIT) production systems (Kaplinsky 2004a:21). In particular, scholars have highlighted how the growing 'asymmetry' between small disaggregated producers and concentrated traders and manufacturers has exerted a downward pressure on prices and undermined political mechanisms of coordination, such as public marketing boards and price controls (Kaplinsky 2004a). In the case of cocoa this spells the end for state regulated supply systems because the demand for world standard bulk cocoa has eliminated the notion of 'national supply' and 'producing country' (Losch 2002:225). According to Fold this has created a 'bi-polar' form of chain governance biased towards huge economies of scale, and although it is less easy to ascertain the exact locus of 'driving' it is clear that 'agricultural producers are more or less price-takers on the global market' (Fold 2002:244).

This downward pressure on prices is reflected by research highlighting dramatic changes in the 'value' retained by cocoa-producing countries which declined from around 60\% in 1970 to around $28 \%$ in 2000 , as a result, it is estimated that smallholder farmers currently receive just 4-6\% of the final consumer price (Abdulsamad et al. 2015:24). This has been linked to the changes driven by cost advantages from variable-quality bulk bean flat transportation methods which dramatically reduced labour costs 'to around a fifth of the levels associated with traditional logistical systems' (Fold 2002:240). Now large processors employ in-house mechanisms to meet quality control standards, thereby reducing the incentive of local buyers to seek quality beans and eliminating 'value-addition' opportunities for smallholders at the farm gate (Tollens and Gilbert 2003). These technological changes have been identified as the 'asymmetric' basis of market power for lead firms, 'effectively blocking the transmission of the generated value upstream to producing countries' (Abdulsamad et al. 2015:41). Yet this notion of blocking the transmission of 'value' also presupposes that 'value' is only created at the downstream (grinding and processing) segment of the chain in separation from the labouring activity of primary producers. However, if highly concentrated industrial processing 
Pre-publication final edit for Antipode.

Article accepted 8/09/2017

is in some way forcing prices down for small holders, we can further interrogate this as a spatial relationship within the overall organization of the production process (Harvey 1982:341). The capacity to reproduce themselves as 'price-takers' rests on their valorization as 'small agrarian capitals', where producers can push their costs below the limits of necessary labour time and even release surplus value downstream. By linking this material basis to so-called 'asymmetry' we can address the silence 'concerning the initial creation of value that precedes its distribution among firms across the supply chain' (Taylor 2008:12). In this light we can reflect on the general tendency within the literature to assert, rather than explain, the way in which 'asymmetry' reduces the capacity of farmers to raise their share of 'rents' (Fitter and Kaplinksky 2001:16). As Starosta (2010b:550) has argued 'power asymmetries are not the cause but an expression' of different valorisation capacities predicated on the essentially indirect social relations of commodity chains. For this task however, we must first address the under-theorised categories of value and rents in the GCC and GVC literature which focus on the industrial phase as the locus of the relationship between asymmetry and rents.

The lack of a 'common theoretical or methodological approach' within chain and network studies (Bernstein and Campling 2006:240), can be seen vividly in what Bridge (2008:414) identifies as a 'catholic' approach to rent. Whilst this 'opens an opportunity to identify different forms of rent and how these can be captured', the major area of focus has been on technological and relational rents; as such there 'is scope to extend this to differential, monopoly and windfall rents which are particularly prominent in extractive sector (Ibid:414). ${ }^{10}$ We agree with this call, but also maintain that epistemological differences mitigate an extension of 'rents' to natural resource based chains. As such we seek to deepen, rather than extend, Marxian concepts of rent within chain analysis. ${ }^{11}$ Indeed, part of the problem is that when 'rents' feature in the literature they are often taken over from notions which equate 'rents' with 'value-added' or use them interchangeably to mean 'profitability' (cf Coe et al. 2004:473). This lack of specificity can be seen across studies of agricultural commodity chains where rents are seen as deriving from 'upgrading' (Gibbon 2001); the return to scarce assets controlled by monopolized segments of the chain (Fitter and Kaplinksky 2001); the product of non-perfect competition within select chain segments (Giuliani et al. 2005); the outcome of successful product differentiation (Humphrey 2006); and the result of political connections and networks of power (Nielson 2008). 
Pre-publication final edit for Antipode.

Article accepted 8/09/2017

A common thread running through these accounts is the focus on the reduction of transaction costs and downstream power and technological relations between firms, where the capture of 'economic rent' is contingent on moving up the value chain. Methodologically, this form of economic sociology takes a Ricardian point of departure for the conceptual existence of rents, mixes in neoclassical assumptions about efficiency and value creation, then reverts to Schumpeterian economic rents to explain their capture by innovating firms or regions moving up the value chain. This tends to obfuscate 'value creation' that lies below inter-firm relations in favour of a catalogue of - technical rather than social - mechanisms which can be used to capture different types of economic rents (Kaplinsky 2004b). ${ }^{12}$ The following section takes up the above outlined Marxian approach to rent in order to provide an historical geographical materialist account of global cocoa chains in Ecuador. In doing so we draw attention the forces that defend (producers) and contest (buyers) the payment of ground rent and thereby shape the spatial geography of primary production within the global dynamics of capital accumulation.

\section{A History of Cocoa Rents}

This first indication of the global cocoa economy in Ecuador can be found in a small replica of the Eiffel Tower set amongst the crumbling facades of French colonial architecture in a town called Vinces. Made rich by the export boom of the late $19^{\text {th }}$ century 'Little Paris' was the seat of the 'Kings of Cocoa', a landed oligarchy who presided over the cultivation and export of the famous "Superior Cocoa Arriba" (“Cacao Arriba Superior”). Driven by the technology and mass markets created by the first industrial revolution, between 1894 and 1924 global consumption of cocoa increased eightfold and, up until 1916, Ecuador was the world's largest producer (Chiriboga 2013:359). The extraordinary profits that came from cocoa exports, accounting for $70 \%$ of total exports and $50 \%$ of foreign exchange earnings, were based upon the superior fertility of the land, low labour costs and a network of natural rivers systems that permitted the cheap transport to the port in Guayaquil (Guerrero 1994).

Notwithstanding the absence of unified world market price, the superior productivity of Ecuadorean cocoa - and brutal labour repression - delivered significant differential rents to landowners (Chiriboga 2013:264). Yet by 1910, French and British colonial investment (led by large commercial trading houses), along with evangelists' development missions, saw West African cocoa production increase rapidly, leading to a situation of general over-production in world markets. The formation of a world market price came out of new competition and with 
Pre-publication final edit for Antipode.

Article accepted 8/09/2017

supply now overtaking demand, Ecuador's capacity to appropriate differential rents began to deteriorate. In response, Ecuador spearheaded the first international cartel, allying with Portugal and Brazil and later, in 1911, convoking the first meeting of producer countries in Paris. The first 'International Association' attempt failed, but Ecuador pushed ahead with the creation of a national 'Farmers Association of Ecuador' which offered higher prices to national producers than competing traders and exported under consignment hoping for prices to rise. Efforts were intensified following the onset of WWI with the fixing of national prices in response to a severe world market decline. The close relations between landowners, exporters and bankers permitted a nine-year period of subsidization, allowing the Farmers Association to reach a 70\% control over the national market (Chiriboga 2013:370-71). The banks continued to print money and uphold prices until 1925, when the situation became unsustainable and a financial crisis spelled the definitive end for the 'Kings of Cocoa'. The inability of Ecuador's producer-driven initiatives to create a monopoly price, along with the large-scale entry of West Africa into the global cocoa sector provides an indication of the way in which the extension of the agrarian frontier diminished the magnitude of differential rent available to the national class alliances formed around the 'Kings of Cocoa'. As a result, any national producers withholding their crop from the international market would only serve to increase the price of cocoa for competing producers, resulting in the appropriation of differential rents by lands still in production (Iñigo Carrera 2007:14).

\section{The limits of state-led upgrading}

Large cocoa plantations disappeared following the market crash in the inter-war period. The Agrarian Reforms of 1964 and 1973 would go on to promote cocoa cultivation as a small peasant-led colonization strategy giving rise to a large geographically disaggregated peasant network of 'small agrarian capitals'. This generated a sustained growth in cocoa cultivation until production volumes stabilized around the late 1970s (Sotomayor 2011:10). It was in the 1970s when the Ecuadorean state - following the global development pattern of producer countries, especially the price controls exercised through government controlled production boards in the Ivory Coast and Ghana (Losch 2002) - rolled out a series of ISI policies to incentivize the national industrialisation of cocoa processing through fiscal incentives, duties exonerations and subsidized machinery imports. By 1976, Ecuador had installed enough industrial capacity to process $100 \%$ of its annual production and by 1978 , only $25 \%$ of the country's raw cocoa could be legally exported as quotas were assigned to firms that could 
Pre-publication final edit for Antipode.

Article accepted 8/09/2017

negotiate on the basis of establishing semi-finished industrial processing (Official Registry 1978:8).

These policies were maintained during the price highs of the late 1970s, however, the national processing sector was never 'upgraded' to the scale or productivity to survive competition at the level of the world market. When the state's capacity to regulate exports and subsidise national industrial cocoa processors was undermined by falling commodity prices, the model began to unravel. Export taxes and quantity controls were gradually reduced and then legally abolished (Official Registry 1980:2), and the regulations introduced to stabilise prices among the national network of producers, processing and purchasing centres were not respected (Burbano 2011:31). As global prices fell from their 1970s historic peak of US\$ 3,000 to US\$ 1,000 per ton by the mid-1980s (Moran 2008:36), a process of deregulation devolved control over the sector to large private exporters (Burbano 2011:31). This phase illustrates how the class alliances of vertical integration that underpinned the producer-driven (PDCC) phase of primary commodity chains (Losch 2002:210), were predicated on three intertwined factors: the formation of a large network of small agrarian capitals providing abundant low costs supplies of cocoa at 'cost price', a conjunctural moment of high global commodity prices (differential rent), and state marketing boards being in a position to regulate prices (monopoly rents). In this light we can see how value appropriated from cocoa production - and other primary commodity exports - in the form of ground rent constituted the social wealth and limited material basis which sustained a short period state developmentalism and investment in national industrialisation (cf Grinberg and Starosta 2009).

\section{Towards Chain Deregulation}

Agrarian reform policies were replaced by The Programme of Rural Development, which initiated the first wave of structural adjustment policies and market deregulation in Ecuador's cocoa sector (Martínez 2014:132). In 1994, all public regulations over prices, quality control and commercialization were repealed and delegated to the National Association of the Cocoa Exporters of Ecuador (ANECACAO). At the same time, conforming to the global trend between liberalization, privatization and cocoa quality (Fold 2002:246), the International Cocoa Organization (ICCO) passed a resolution downgrading Ecuador from a $100 \%$ to a $75 \%$ producer of fine aroma cocoa (Troya 2013:53). This downgrading was linked to the deterioration of post-harvest quality control (fermenting and drying) and to the introduction of a new cloned variety of cocoa (CCN-51), that was lower in quality but much higher in yield 
Pre-publication final edit for Antipode.

Article accepted 8/09/2017

per hectare, making use of modern fertilizers in large mono-culture plantations. The introduction of $\mathrm{CCN}-51$ was the main strategy to boost production volumes and attract new investment as part of the 'Cocoa Revitalization and Quality Improvement Project'. The final phase of deregulation saw the elimination of the National Cocoa Program in 1995, leaving small producers without any economic or technical support and at the mercy of an unregulated chain of private intermediaries, exerting further downward pressures on producer prices.

It is in this context that the chamber of commerce ANECACAO and transnational players took control over Ecuador's cocoa sector. In the 1990s Transmar Group, a U.S. based company, was the first foreign capital to open an export office in Guayaquil. Transmar's access to external capital permitted the inauguration of a vertically integrated buyer-driven chain, locating processing centres and offering technical assistance in known quality production areas. ${ }^{13}$ This intensified local price competition, injecting large amounts of capital and offering a large enough premium per sack (5 to 10 US\$ Dollars) to attract the custom of small local producers, sometimes with credit. Once the competing processing centres organised around small producer associations were forced out of business, or when they lacked the capital to offer producers alternative outlets, Transmar would drop the price offered to a captive local market. ${ }^{14}$ By 2011, Transmar exported 24,500 tons of cocoa (25\% in semi-finished cocoa liquor and 75\% in raw bean). For semi-finished products their clients include Mars in the United States and Ritter Sport in Europe, whilst their cocoa in grain is sold to the large trading houses that dominate world grinding capacity such as Archer-Daniels-Midland (ADM), Cargill, Barry Callebaut and Nestle. ${ }^{15}$ Transmar is emblematic of a handful of national-based export companies that source cocoa from a network of unregulated intermediaries and producer associations. GCC scholars have usefully shown how this type of hands-off governance makes 'concentration at one point of the chain' compatible with 'continuing fragmentation at other points' (Humphery 2006:37). Whilst this accurately captures important organisational features, this type of description provides only a partial view of the class alliances and institutional contexts which shape local production and mediate its developmental impacts (cf. Taylor 2008). The following section takes up this task through an empirical investigation into the interface between the fragmented supply chain and the government's attempt to assume a developmental role by boosting the productivity and quality of small producers' output.

\section{Reactivating Fine Aroma Cocoa}


Pre-publication final edit for Antipode.

Article accepted 8/09/2017

Led by the Ministry of Agriculture (MAGAP), government intervention aims to reactivate and boost the production (through pruning cocoa trees) and export of fine aroma cocoa and incentivize, where possible, the 'added value' production and processing of finished and semifinished products within the country. The latter objective has mainly been driven, quite unsuccessfully, by incentives offered to foreign investors to undertake more industrial processing within Ecuador. ${ }^{16}$ As such the project has largely focused on improving production conditions at the root of the chain. As MAGAP's general manager of the national 'Reactivation Project' put it, 'fine aroma cocoa is very difficult to replicate, it is our comparative advantage'. ${ }^{17}$ Fine aroma cocoa makes up only $6 \%$ of the total international market, however Ecuador has a $63 \%$ share of this market making it by far the largest producer of the raw ingredient for high-value cocoa markets. Nevertheless, as we explain below, this market share is not representative of successful penetration into premium contracts (monopoly rents) for the 100,000 families in Ecuador that rely on the small scale cultivation of fine aroma cocoa as a source of income. In 2013 cocoa represented \$500 million in foreign exchange earnings for Ecuador, ${ }^{18}$ an extremely important stream of revenue for a dollarized economy without the ability to devalue or print money (Purcell et al. 2016). The significance of foreign exchange earnings emerged as central to the institutional and class alliances - the exporters, intermediaries and commercial interests formed around the cocoa chamber of commerce (ANECACAO) - that coalesce around primary exports.

\section{Non Associated and Associated Producers: Price, Value and Rents}

According to national statistics the cultivation of fine aroma cocoa is carried out by 115,000 producers, $90 \%$ of whom are farmers with less than 5 hectares of land (Vicepresidencia de la República, 2015). These producers have levels of productivity per hectare that are among the lowest in Latin America and lack post-harvest quality control systems (fermentation and drying) that sees $\mathrm{CCN}-51$ routinely mixed with fine aroma cocoa, leading to the penalization of Ecuador's exports on world markets. ${ }^{19}$ The production chain in which an estimated 50,000 non-associated producers - those territorially isolated without a sales affiliation to a legally recognised cocoa organisation - ply their trade is made up of around 1,000 commercial intermediaries who forward credit, exchange basic goods (rice, corn, sugar) in lieu of cash, provide collection services and constitute the main bridge to processing centres, brokers and exporters. This intermediary chain includes local buyers and agents, area traders and national wholesale traders. The national chain culminates in Guayaquil where there are no more than ten bulk export companies buying from wholesalers. Within this export monopoly, the biggest 
Pre-publication final edit for Antipode.

Article accepted 8/09/2017

company is Transmar and together these companies control close to $70 \%$ of national production, almost all Ecuador's export volume. ${ }^{20}$ The chain of intermediaries is driven by weekly orders for mass undifferentiated volumes. Turnover speed and securing quotas are central for intermediaries as they often function on credit from large exporters which they in turn lend, pre-harvest, to small producers. ${ }^{21}$ As the president of a producer's association explained:

... the brokers sell cheap to large trading companies like Blommer, ADM or Barret, because they want cheap cocoa to be competitive; the brokers pays low prices to the Ecuadorean exporter because they cannot pay more and the Ecuadorean exporter pays even less to the producers and here we enter into the game of cheap cocoa. ${ }^{22}$

Given that profit margins on the physical side of trading in undifferentiated volume are very low, intermediaries are known to take advantage of interest rate differences on loan capital and cheat on weight per sack often buying at prices up to $30 \%$ below the weekly market rate. ${ }^{23}$ This highlights one way in which the fragmented supply chain functions as a relation of production pushing small producer prices below market prices to 'cost price', eradicating any potential differential rent from increased productivity and even dispossessing small producers of their own surplus labour (Vergopoulos 1978:447). This value relation is mediated by the local production conditions and the formation of different market prices for cocoa varieties. In the absence of the institutional infrastructural support necessary to even secure normal market prices, fine aroma cocoa is regularly mixed with $\mathrm{CCN}-51$ in order to boost volume and fulfil contracts struck with intermediaries. For these non-associated producers then MAGAP's productivity drive has incentivised the speculative activity of intermediaries and intensified the logic of undifferentiated volume for export. As one intermediary from the Guayas region explained this tends to push down farm gate prices,

A non-associated producer can't sell his cocoa for $\$ 130$ [market price] a sack, but for $\$ 105$ a sack. He sells at \$105 because the intermediary sells for $\$ 110$ in Guayaquil and the exporter can't pay more than $\$ 110$ because he sells at $\$ 120$ and they have to cover their costs. Therefore, the producer doesn't receive more because the Ecuadorean intermediaries, we are also victims of international market manipulation and non-differentiated prices. 
Pre-publication final edit for Antipode.

Article accepted 8/09/2017

In the case of associated producers and cooperatives it is possible to identify different local institutional mechanisms designed to shield producers from the pressures of the deregulated low margin system of mass export. Associations are legally registered entities that provide buying and processing centres (centros de acopio) with the objective of improving prices, defending producer interests and improving the quality of post-harvest processing (Troya 2013:47). It is estimated that around 19,000 producers belong to 50 associations across the territory (Ramírez 2012:6). However, the majority of associations function in extremely strained financial conditions, lacking the capital and technological capacity to meet manifold producer needs or establish their own export contracts. In fact, only a small minority have managed to establish a foothold outside the bulk cocoa market.

\section{Fine Aroma Associations and Cooperatives: Monopoly Rents}

The market for fine aroma cocoa is relatively small, specialised and functions in separation from the international market for bulk cocoa. ${ }^{24}$ In the best of cases when associations have managed to purchase fair trade certificates, implemented organic production techniques among their producers and secured fixed supply contracts with niche buyers, normally in the US and Europe, they can pay a premium to their producers. The premium (monopoly rent) is based on the ability to sell fine aroma cocoa between US\$ 200/ton and US\$300/ton over the world market reference price set by the highest grade Ghanaian cocoa (Troya 2013: 47). One flagship example of a fine aroma cocoa association with producer premiums of around $\$ 30$ per sack that we visited was the APROCA cooperative situated on the coast in Esmeraldas. With certification from 'Rainforest Alliance', previous financing from USAID, MAGAP and the provincial government, APROCA supplies the US based chocolate manufacturer Tcho and the national manufacturer PACARI. On its website, Tcho extols the virtues of their 'unique sourcing program dedicated to partnering directly with our growers', and PACARI has successfully marketed itself internationally as a biodynamic, organic, Kosher, fair trade producer with close relations with small Ecuadorean producers. The chocolate bars of these firms' retail at the luxury end of the market, aimed at consumers willing to pay price premiums for guarantees over quality control, taste, labour standards and traceability.

Although internally related, there is an uneven differentiation in the formation and magnitude of monopoly rents for these niche primary producers and manufacturers. In both cases it is the price - world market and retail respectively - that creates the monopoly rent. However, meeting 
Pre-publication final edit for Antipode.

Article accepted 8/09/2017

the exacting standards functions as a form of control over small producers and their associations, requiring increased labour time and capital investment to maintain quality required by niche market outlets. Whilst this can certainly increase producer income and improve farm conditions for a privileged segment of small producers, a significant portion of the price premium can also escape their hands forming an 'inverse flow of rent' for capital (Vergopoulos 1980:167). For example, commenting on the producer-buyer relations between APROCA and PACARI, the general manager of MAGAP's cocoa project commented that the cumulative costs of fair trade certificates, organic and biodynamic production techniques mean that a very meagre portion of the monopoly price is appropriated by producers. For it to be 'just' the company in question should double or triple what it pays the producers. ${ }^{25}$

At the manufacturing and commercialisation end of this chain the number of specialist companies is limited by the sheer capital requirements of fulfilling premium priced fixed supply contracts (Fold 2002:239). The price per sack of fine aroma cocoa is based on a bargaining process between the association and the manufacturers' willingness to pay a monopoly price depending on a pre-sample of proven quality. It is estimated that this niche market only represents around 20,000 tons a year for Ecuador, which intensifies competition between small Ecuadorean producer associations for expensive organic and fair trade certificates. $^{26}$ For example, PACARI was considered a sui generis case of successful 'upgrading' within a niche segment of the market through public support and international marketing, but with very limited industrial processing capacity. PACARI can only process around 100 tons a year and buys less than $50 \%$ of APROCA's annual production. ${ }^{27}$ APROCA is then forced into selling a portion of their output to intermediaries speculating on the weekly movement of world market prices. Commenting upon limited market volumes and dependence upon buyers, one producer explained that,

there are organisations that can have the best cocoa in the world that want to charge a $\$ 500$ premium, but obviously they have a very reduced market. I know organisations that sell a sack of cocoa for $\$ 200$ each, but how many sacks do they sell a year, 1,000? It is not sustainable. What do I want to sell? A popular car that everyone in the world can buy or a Mercedes Benz? ${ }^{28}$

In this light we can see that the 'upgrading' of the national firm PACARI and the ethical standards preached by Tcho rests, in part, on the extra labour time and costs borne by primary 
Pre-publication final edit for Antipode.

Article accepted 8/09/2017

producers and their associations. Therefore, although the production relations of associated and non-associated producers are shaped by distinct chain segments, both function as potential sources of an inverse flow of value and rent for capital.

Another prominent association of fine aroma cocoa producers is UNOCACE which directly exports 6,000 tonnes annually through an innovative price fixing policy. Legally created in 1999, UNOCACE is composed of 12 organizations in five provinces of Ecuador which amounts to almost 1,000 small producers covering nearly 5,000 hectares. Through MAGAP's reactivation program, UNOCACE has pruned over 500,000 trees, significantly boosting productivity. In 2014, UNOCACE managed to pay their producers a consistent $\$ 140$ per sack, $15 \%$ above the market, as the President stated 'it was always our intention to escape market speculation'. The model, developed to ride-out the vagaries of international prices and keep producer prices, including premiums, within a steady margin of world market oscillations is based upon taking the previous month's average price as the benchmark. Through negotiations with their foreign clients and an agreement with producers, UNOCACE maintained stable prices in spite of weekly market volatility. ${ }^{29}$ In this way UNOCACE guarantees a fixed price with its producers and has built a strong reputation and relationship with international clients. However, the agency of UNOCACE is constrained by its strategy to defend monopoly rents rather than create or 'add value' in the sense articulated by the GCC/GVC literature. This is possible through control over their own logistics, exporting directly to clients, and access to an international source of credit thereby escaping exorbitant national interest rates. Preferential access to capital from a Dutch non-profit organisation, (which allows them to extend interest free loans to their associated producers thus supporting the turnover cycles of each contract), is exceptional among producer associations as the majority function in extremely strained financial conditions and are unable to defend producer prices. From this perspective, the premium secured by UNOCACE and APROCA is not only a limited form of 'upgrading' secured through 'moving up the quality grade ladder, increasing volumes and reliability of supply' (cf Gibbon 2001:352), but also predicated on a potentially ephemeral portion of monopoly rent dependent on bargaining within niche supply contracts.

\section{The political economy of the mix and constrained producer power}

By the end of 2014 cocoa exports had grown by $18 \%$ which represented an extra 28,000 tonnes and almost US $\$ 85$ million in extra foreign exchange earnings. ${ }^{30}$ This has been appropriated largely by national second-tier suppliers through access to higher volumes of cheap cocoa. In 
Pre-publication final edit for Antipode.

Article accepted 8/09/2017

the short term what interests MAGAP is reaching an extra annual 300,000 tonnes in export volume, before any extra control measures such as price differentiation for small producers or export taxes and quotas for national industrial processing would be countenanced. ${ }^{31}$ This was evident in March 2015 when the Ecuadorean National Assembly rejected as un-constitutional a new law for the 'Promotion and Development of Fine Aroma Cocoa' (Ley de Fomento y Desarrollo del Cacao Nacional Fino de Aroma) that was tabled by a collection of producer associations. After a concerted period of campaign, dialogue and lobbying small producer associations proposed measures in the new law to legally prohibit (through financial penalties) the mixing of cocoa varieties, to allow price differentiation according to quality and to create an extra layer of institutional support and regulation for the small producers of fine aroma cocoa. In particular, private export associations reacted against a proposed $1.5 \%$ export tax on each ton of cocoa in order to fund a new National Cocoa Council that would oversee regulation in the sector. Officially the law was 'archived' on the grounds that MAGAP's programs are sufficiently addressing the sector's needs, that agrarian legislation cannot be sector specific and new provisions to protect small producers will form part of a general agrarian law still under construction.

In addition, it was clear that public regulation of local quality control and product differentiation (avoiding mixing $\mathrm{CCN}-51$ and fine aroma) - measures that would reinforce producer bargaining power - infringed on the interests of large exporters. ${ }^{32}$ It was highlighted that notwithstanding huge variations in quality 'all' Ecuadorean cocoa is sold and that national exporters such as Transmar do in fact sort and differentiate cocoa in Guayaquil before export, 'the trick is saying to producers and intermediaries "don't mix", [if you want better prices] but their secret is benefitting from the mix'. ${ }^{33}$ As noted above, the sophistication of processing technology means that mixed varieties and qualities of cocoa bought at bulk market rates from geographically dispersed small producers and delivered to Guayaquil by a large network of debt-financed intermediaries can then be sorted in-house according to grade quality. This from of 'upgrading' does not permit the capture of rents from international traders in the sense assumed by 'localising commodity processing' (cf Gibbon 2001: 354), but rather permits the private firm-based appropriation of value from direct producers when selling at price differentials to international traders. ${ }^{34}$ Thereby allowing the large national exporters in their role as second tier suppliers to individually appropriate a portion of the monopoly rent carried by fine aroma cocoa. This shines a light on the struggle over ground rent along the cocoa 
Pre-publication final edit for Antipode.

Article accepted 8/09/2017

GCC/GVC in Ecuador, a class politics which is not missed by small producers and their associations who continue to lobby for greater reforms. ${ }^{35}$

\section{Conclusion}

This paper has offered a theoretical framework grounded in Marxian rent theory to understand the historical development of value relations which confront small producers at the root of the cocoa GCC in Ecuador. Given that one of the specificities of tropical commodity cultivation is the global existence of poor small-owner producers, we demonstrated the importance of theorising the value constitution of commodities produced on the land rather than restricting analyses to the payment for use of the land (Iñigo Carrera 2007). This opened up the analytical space to consider the valorisation specificities of small agrarian capitals - in other words, how valuable tropical commodity chains can function on the backs of poor small-owner producers - and the social subjects, other than landlords, involved in the appropriation, and contestation, of the payment of ground rent. Engaging with the theorisation the primary commodity focused GCC/GVC literature, we argued that the 'catholic' approach to 'rent' underspecifies the locus value creation and the mechanisms which permit its capture and transfer before its journey into inter-firm chain relations. Working with the notion that 'value creation' is primarily located downstream, research has marginalised the labour of primary commodity production as a critical factor in the overall 'profitability' of the chain. However, by treating concentrated industrial processing and trading as a spatial relation of production (Harvey 1982; Bernstein and Campling 2006), we were able to explore the value relations that lie at the interface of the competitive fragmented supply chains. In doing so we went beyond accounts that have described the 'asymmetrical' chain governance relations placing downward pressure on 'prices' for small producers, by enquiring into the value and rent relations that hide behind the price form.

This framework informed our historical geographical materialist narrative of the evolution of cocoa cultivation and export in Ecuador. Drawing attention to the forces that contest the payment of ground rent, and thereby shape the spatial geography of primary production within the global dynamics of capital accumulation, we highlighted three principal phases: the early $20^{\text {th }}$ century extension of the global cocoa frontier to undo the monopoly of lands already under production; state-led price regulation during the commodity price highs of the 1970s which permitted a limited period of producer-driven chain integration and industrial subsidisation; and finally, the dual forces of concentration and disaggregation during the rise of neoliberal 
Pre-publication final edit for Antipode.

Article accepted 8/09/2017

reforms which produced the fragmented supply chain linking small agrarian producers indirectly with the global cocoa commodity chain. Our empirical investigation into Ecuador's current 'post-neoliberal' intervention into the cocoa sector examined how the class alliances and institutional contexts shaped local production and mediated the developmental impact of fine aroma cocoa reactivation. This manifest itself in the pre-export chain where national second tier suppliers - the modern day 'Kings of Cocoa' - do carry out ex-post sorting and processing thus selling the cocoa at higher prices and appropriating a portion of rent that has escaped the hands of small producers. In the light of this analysis, the current project can be seen as a form of light touch intervention facilitating an essentially market-based regulation. Whilst increased productivity carries with it the ephemeral prospect of monopoly rents for producer associations selling to gourmet manufactures satisfying the consumers with a penchant for high quality or fair trade chocolate, the majority of small producers continue as suppliers of non-differentiated bulk cocoa at 'cost-price' for domestic export. Therefore, we can say that the 'post-neoliberal' state-led initiative is largely concerned with increasing inflows of foreign exchange whilst reproducing its functional role in the increasingly concentrated and volume hungry global buyer-driven cocoa chain.

This brings us full circle and allows us to provide a value-theoretic reformulation of the way in which 'asymmetry' functions in relation to value and rents within the global cocoa chain in Ecuador. As is the case with all commodity production, the formation of market prices for bulk and fine aroma cocoa systematically deviates from the labour time (value) and the productivity of cultivation (rent) experienced by direct producers. The uneven production relations within the chain faced by small agrarian capital - for whom normal profits and rents do not enter into costs of production - is expressed through the release of surplus value downstream. Thus, opposed to a one-way direct relation of power forcing down producer prices and blocking the upstream transmission of value, the indirect 'asymmetry' which confronts small cocoa producers is their inability to retain a portion of ground rent or even secure normal profits. In this light we can see that MAGAP's policy of fine aroma reactivation without touching the fragmented supply chain, is reproducing the same subsistence conditions that have led commentators to identify cocoa cultivation as the 'business of poverty'. Here we can see how, following the local saying, cocoa continues to be 'the piggy bank of the poor.' Indeed, according to the Marxian approach to value theory, increasing the productivity of labour does not 'add value' but increases the amount of use values produced within a given turnover period. So a small owner producer with more productive land but without the capacity to retain extra 
Pre-publication final edit for Antipode.

Article accepted 8/09/2017

value in the form of differential rent or even normal profits, does not capture 'added value', but only increases the volume of cocoa she can sell at the often depressed market price. In this way we might reformulate the local saying and note that the fragmented supply chain has many hands in the piggy bank.

\section{References}

Abdulsamad A, Frederick S, Guinn A and Gereffi G (2015) Pro-poor development and power asymmetries in global value chains. Duke University, Center on Globalization, Governance and Competitiveness

Bair J (2005) Global capitalism and commodity chains: Looking back, going forward. Competition and Change 9(2): 153-180

Ball M (1985) The urban rent question. Environment and Planning A 17(4):503-525

Bartra A (2006) El capital en su laberinto. De la renta de la tierra a la renta de la vida. México: UACM/Ítaca, CEDERSSA

Bernstein H (2002) Land Reform: Taking a Long(er) View. Journal of Agrarian Change $2: 433-463$

Bernstein H and Campling, L. (2006) Commodity Studies and Commodity Fetishism I: Trading Down. Journal of Agrarian Change 6 (2): 239-64

Bridge G (2008) Global production networks and the extractive sector: governing resourcebased development. Journal of Economic Geography 8 (3):389-419

Burbano M (2011) Ecuador de exportador del mejor cacao del mundo a Exportador del mejor chocolate del mundo. Tesis Programa de Economía, FLACSO-Ecuador

Chiriboga M (2013) Jornaleros, grandes propietarios y exportación cacaotera 1790-1925. Ecuador: Corporación Editora Nacional, Universidad Andina Simón Bolívar

Coe N, Hess M, Yeung H, Dicken P and Henderson J (2004) 'Globalizating' regional development: a global production network perspective. Transactions of the Institute of British Geographers 29: 468-484

ECLAC (CEPAL) (2012) Cambio Estructural para la Igualdad: Una visión integrada del desarrollo. San Salvador: CEPAL

Elden S and Morton A D (2016) Thinking past Henri Lefebvre: introducing "the theory of ground rent and rural sociology". Antipode 48: 57-66

Fierro L (1986) Los grupos financieros en el Ecuador. Quito: CEPEP Fine B (1979) On Marx's theory of agricultural rent. Economy and Society 8(3): 241-278 
Pre-publication final edit for Antipode.

Article accepted 8/09/2017

Fitter R and Kaplinsky R (2001) Can agricultural 'commodity' be de-commodified, and if so who is to gain? University of Sussex, Brighton: Institute of Development Studies

Fold N (2002) Lead Firms and Competition in 'Bi-polar' Commodity Chains: Grinders and Branders in the Global Cocoa-chocolate Industry. Journal of Agrarian Change 2(2): 228247

Fold N and Pritchard B (2005) Cross-continental Food Chains London and New York: Routledge

Gereffi G (1994) The organization of buyer-driven global commodity chains: How US retailers shape overseas production networks. In G Gereffi and M Korzeniewicz (eds) Commodity Chains and Global Capitalism (pp 95-122). Westport, CT: Praeger

Gibbon P (2001) Upgrading primary production: a global commodity chain approach. World Development 29(2): 345-363

Gibbon P and Ponte S (2005) Trading Down: Africa, Value Chains, and the Global Economy. Philadelphia: Temple University Press.

Giuliani E, Pietrobelli C and Rabelloti R (2005) Upgrading in Global Value Chains: Lessons from Latin American Clusters. World Development 33(4): 549-573

Grinberg N and Starosta G (2009) The limits of studies in comparative development of East Asia and Latin America: the case of land reform and agrarian policies. Third World Quarterly 30(4): 761-777

Guerrero A (1994) Los Oligarcas del Cacao. Quito: Editorial El Conejo

Guthman J (2004) Back to the land: the paradox of organic food standards. Environment and Planning A 36: 511-528

Haila A (1990) The theory of land rent at the crossroads. Environment and Planning D 8(3): $275-296$

Harvey D (1982) The Limits to Capital. London: Verso

Harvey D (1985) Land rend under capitalism. In The urbanization of capital: studies in the history and theory of capitalist urbanization. Baltimore: Johns Hopkins University Press

Hopkins T and Wallerstein I (1986) Commodity chains in the world-economy prior to 1800. Review 10(1): 157-170

Humphery J (2006) Global Value Chains in the Agrifood Sector. Institute of Development Studies University of Sussex, Brighton, United Kingdom, United Nations- Industrial Development Organization

Iñigo Carrera J (2007) La Formación Económica de la Sociedad Argentina. Buenos Aires: Imago Mundi 
Pre-publication final edit for Antipode.

Article accepted 8/09/2017

Jäger J (2003) Urban land rent theory: a regulationist perspective. International Journal of Urban and Regional Research 27(2): 233-249

Kaplinsky R (2004a) Spreading the Gains from Globalisation: What can be learned from Value Chain Analysis. IDS Working Paper 110

Kaplinsky R (2004b) Globalisation, industrialisation and sustainable growth: the pursuit of the NTH rent. IDS Discussion Paper 365

Kautsky K (1988). The agrarian question, 2 volumes. London: Zwan Publications. First published in 1899.

Kerr D (1996) The theory of rent: from crossroads to the magic roundabout. Capital and Class 20(1): 59-88

Losch B (2002) Global Restructuring and Liberalization: Côte d'Ivoire and the End of the International Cocoa Market? Journal of Agrarian Change 2(2): 206-227

Martínez L (2014) De la hacienda al agronegocio: agricultura y capitalismo en Ecuador (pp 123-155). En G Almeyra, L Concheiro, J Mendes \& C Porto-Gonçalves Capitalismo Tierra y Poder en América Latina (1982-2012) Vol. II. México: CLACSO-Ediciones Continente- Universidad Autónoma Metropolitana

Marx K (1981) Capital Vol III. London: Penguin

Neilson J (2008) Global Private Regulation and Value-Chain Restructuring in Indonesian Smallholder Coffee Systems. World Development 36(9): 1607-1622

Official Registry (1978) Acuerdo Interministerial No. 1183, Ministerio de Industrias, Comercio e Integración, y Ministerio de Agricultura y Ganadería, Registro Oficial No. 707, Noviembre 9, 1978, p. 8

Official Registry (1980) Decreto Legislativo, Cámara Nacional de Representantes, Registro Oficial No. 113, Enero 24, 1980, pp 1-2

Purcell T, Fernandez N and Martinez E (2016) Rents, knowledge and neo-structuralism: transforming the productive matrix in Ecuador. Third World Quarterly DOI: 10.1080/01436597.2016.1166942

Raikes P, Jensen M and Ponte S (2000) Global Commodity Chain Analysis and the French filiare Approach: Comparison and Critique. Economy and Society 29(3): 390-417

Ramírez P (2012) Breve Caracterización de la Cadena de Cacao en los Niveles: Mundial, Nacional, Amazonia Norte y Provincia de Napo. Ecuador: GIZ

Selwyn B (2011) Beyond firm-centrism: re-integrating labour and capitalism into global commodity chain analysis. Journal of Economic Geography (2011): 1-22 
Pre-publication final edit for Antipode.

Article accepted 8/09/2017

Sotomayor D (2011) Estimación de los retornos de las inversiones realizadas por INIAP en investigación y transferencia de tecnologías en Cacao, Ecuador (2000-2010), Tesis

Ingeniería Agropecuaria, Escuela Politécnica del Ejército, Ecuador

Starosta G (2010a) Global commodity chains and the Marxian law of value. Antipode 42(2): $433-465$

Starosta G (2010b) The outsourcing of manufacturing and the rise of giant global contractors: a Marxian approach to some recent transformations of Global Value Chains". New Political Economy 15(4): 543-563

Talbot J M (2002) Tropical commodity chains, forward integration strategies and international inequality: coffee, cocoa and tea. Review of International Political Economy 9(4): 701-734

Taylor M (2008) Rethinking the global production of uneven development. Globalizations 4: $529-542$

Troya M (2013) Acción colectiva y cadenas de valor estudio de caso: Cadena de cacao y UNOCACE. Tesis Maestría en Ciencias Sociales con Mención en Desarrollo Territorial y Local, FLACSO Ecuador

Tollens E F and Gilbert C L (2003) Does Market Liberalisation Jeopardise Export Quality? Cameroonian Cocoa, 1988-2000. Journal of African Economies 12(3): 303-342

Vergopoulos K (1980) Capitalismo disforme. El caso de la agricultura en el capitalismo. In Amin S and Vergopoulos K La cuestión campesina y el capitalismo. Mexico D.F.: Editorial Nuestro Tiempo

Vergopoulos K (1978) Capitalism and peasant productivity. The Journal of Peasant Studies 5(4): 446-465

Vicepresidencia de la República (2015) Dianóstico de la Cadena Productiva del Cacao en Ecuador (Resumen). Quito: CEPAL,Vicepresidencia del Ecuador y MAGAP

\section{Endnotes}

\footnotetext{
${ }^{1}$ The research for this paper was conducted in 2015, as part of the National Strategy Centre for the Right to Territory (CENEDET) housed at the state postgraduate university the Instituto de Altos Estudios Nacionales (IAEN) and directed by the Marxist human geographer David Harvey. As scholars operating within the Ecuadorian state apparatus, we benefitted from in-depth interviews within the Ministry of Agriculture (MAGAP) and their team leading the National Cocoa Reactivation project. We also travelled extensively across cocoa producing zones in Ecuador carrying out 25 semi-structured interviews with small cocoa producers (15), intermediaries (3), exporters (2) and producer associations (5). Our primary concern in generating a reliable sample of information was to speak to and visit producers and associations beyond those 'flagship' examples we were introduced to by MAGAP. Through a network of local contacts, we endeavored to interview those voices with different experiences of the government's cocoa project. We accessed statistical data for the sector as a whole
} 
from the office of the Vice President and MAGAP, but relied on first hand field work interviews with intermediaries and small producers for information around farm-gate prices, differential prices in processing centres and information such as interest rates on loan capital. This latter sample therefore offered greater validity than 'official' sources, but given its small-size it is certainly not taken, or used as, generalizable for all production. Instead, our interest was to build a qualitative picture of the production relations and local chain dynamics across different cocoa producing territories.

2 This can be seen in the appeal to critical realism (Haila 1990), French regulation theory (Jäger 2003) and more recently, in the pages of this journal, the work of Henri Lefebvre (see Elden and Morton 2016).

${ }^{3}$ Following Marx, any payment to access natural resources is called 'ground rent' (Marx 1991: 755-56). In what follows we sometimes use rent as shorthand, but this should not be confused with the general and unspecified use of 'rent' within the GCC/GVC literature.

${ }^{4}$ Prices of production of commodities include cost prices of labour power and means of production, plus the normal profits of capital, that is, the general rate of profit on the total capital advanced for its production (Marx, 1981:257-8).

${ }^{5}$ Here we bracket the distinction between DRI (same amount of capital invested in different quality lands) and DRII (the intensive investment of capital on the same land), because, as we show below, cocoa production is one of the least mechanised and labour intensive forms of primary production giving it an extensive rather than intensive character. For further elaboration see Marx, Capital Vol III, pp 779-87, 882-907, and 910.

${ }^{6}$ Ricardo equated the value of a commodity with its embodied labour time and as such could not differentiate between value and price. Instead, Marx's theory of socially necessary labour time argued that commodity values are based on the average labour time required for production under current techno-social norms, showing that price and value could deviate without contradicting the labour theory of value.

${ }^{7}$ Harvey (1985:92) stops short of considering 'the payments embodied in commodities', because his simplifying assumptions are designed only to consider payments made directly for the use of land.

${ }^{8}$ Even though labour intensive small scale cocoa cultivation is characterised by a low OCC, because of the absence of the barrier of landed property value is not retained in the form of absolute rent. For this reason, we employ the categories of differential and monopoly rent in what follows to trace out the transfer and outflows of value from cocoa production.

${ }^{9}$ Differential rent is captured indirectly (at market prices) through the manipulation of export taxes which allows the state to divert a portion of surplus profits - the ground rent - away from the landlord's pocket. Monopoly rent is captured directly by state marketing boards that regulate prices and charge capital a monopoly price for access to the primary commodity (Iñigo Carrera 2007:11-13).

10 This applies to extraction and cultivation (i.e. agriculture) (see Bridge 2008).

${ }^{11}$ However, see Guthman (2004:517-518) who differentiates rents - those generated in the intangible parts of the value chain like patents creating barriers to entry - from ground rent as a payment on land as a factor of production. Guthman's eclectic strategy is not concerned with 'overly contested technicalities' but the 'basic insights' which can be applied to the unintended consequences of organic certification schemes. As we explained in the first part of this paper in order to locate the particular within the general ground rent is inseparable from the form of its valorisation (from value theory) and therefore is at epistemological odds with the way in which GCC/GVC approaches equate rents with added-value.

${ }^{12}$ For example, Kaplinsky's (2004b:15) heuristic approach names nine different forms: resource rents, policy rents, technology rents, human resource rents, organisation rents, relational rents, product and marketing rents, infrastructural rents, and finance rents.

${ }^{13}$ Interview, General Manager Agromaquita 26/03/2015.

${ }^{14}$ Interview Pepa de Oro 28/03/2015.

15 Together these companies control $40 \%$ of world grinding capacity.

${ }^{16}$ The French company SALP, a producer of semi-finished cocoa production, has been the only foreign producer to take up incentives offered under the new Production Code (5 years free of income tax). However, they too are geared towards primary production and raw exports rather than industrial processing of semi-finished cocoa products (Interview PROECUADOR, 23/03/2015).

${ }^{17}$ Interview, MAGAP 09/02/2015.

${ }^{18}$ Interview MAGAP, 09/02/ 2015.

19 The project began in 2011 with an investment of US\$ 130 million over or ten years. MAGAP is leading the first stage termed 'La Gran Minga de Poda', a tree maintenance activity designed to increase productivity from $6 \mathrm{qq} / \mathrm{ha}$ to $15 \mathrm{qq} / \mathrm{ha}$ along with the restoration of 354,000 hectares and the expansion of new cultivation by 77,000 hectares. The ambitions of the project include a strategy of differentiation and traceability, which will come in the second phase called 'La Gran Minga de Poscosecha'.

${ }^{20}$ Interview, MAGAP 09/02/2015.

${ }^{21}$ Field observations suggested the interest rates ranged from $3 \%$ to $17 \%$, which, as is usually the case, had an inverse relation to size, success and access to capital. 
22 Ibid.

${ }^{23}$ Interview UNOCACE, 27/03/2015.

${ }^{24} \mathrm{See}$, https://www.icco.org/about-cocoa/fine-or-flavour-cocoa.html.

${ }^{25}$ Interview, MAGAP 09/02/2015.

${ }^{26}$ Interview, General Manager Agromaquita 26/03/2015.

${ }^{27}$ Interview, Atacames Cocoa Producer 27/02/2015.

${ }^{28}$ Interview, Manager Sabor Arriba 21/02/2015.

${ }^{29}$ Interview, UNOCACE 27/03/2015.

${ }^{30}$ Interview, MAGAP 09/02/2015.

${ }^{31}$ Ibid.

${ }^{32}$ Interview, UNOCACE 27/03/2015.

${ }^{33}$ Interview, Sabor Arriba 21/02/2015.

34 The state policies to achieve this are export controls (tariffs and taxes) on primary commodities, public investment in processing and infrastructure along with training and export finance (Gibbon 2001:534). As this section shows, the fact that such policies have not been countenanced by the Ecuadorean government is a political decision to secure foreign exchange from basic export promotion whilst playing lip service to national industrial processing strategies.

${ }^{35}$ Interview AN (17/05/2015). 